\title{
Allometry of cadmium and zinc concentrations and bioaccumulation in the scallop Chlamys nobilis
}

\author{
Ke Pan, Wen-Xiong Wang* \\ Department of Biology, The Hong Kong University of Science and Technology (HKUST), Clear Water Bay, Kowloon, \\ Hong Kong, SAR
}

\begin{abstract}
Scallops (Bivalvia: Pectinidae) contain very high concentrations of cadmium (Cd) and zinc $(\mathrm{Zn})$ in their body tissues. We investigated the allometry of $\mathrm{Cd}$ and $\mathrm{Zn}$ concentrations in the scallop Chlamys nobilis and the underlying biokinetic mechanisms. The metal influx rate from the dissolved phase and the weight-specific clearance rate decreased with body size, whereas the dietary assimilation efficiency (AE) increased with increasing body size. The dietary AEs of metals in the scallops were comparable when measured by the mass balance and the dual radiotracer techniques. The efflux rate of $\mathrm{Cd}$ in the scallops was lower than those in other bivalves, whereas the efflux of $\mathrm{Zn}$ was comparable to those in other bivalves. Growth dilution appeared to be important in the overall metal accumulation in the scallops. The allometric dependencies of the biokinetic parameters were then combined with the measurements of metal concentrations in the water to predict the likely metal concentrations in scallops of different sizes using the biokinetic model. The modeling suggested that the very high $\mathrm{AE}$ and low efflux rate for $\mathrm{Cd}$ explained the high $\mathrm{Cd}$ concentrations in the scallops. Dietary uptake dominated the overall metal accumulation in the scallops. Both the predicted metal concentrations and the allometric coefficients of metals were comparable to the measured values. This study shows, for the first time, that the biokinetic model can be used to predict the effects of body size on the bioaccumulation of metals in marine invertebrates. The allometry of ingestion rate, compared to other biokinetic parameters, is mainly responsible for the allometry of metal bioaccumulation in the scallops.
\end{abstract}

KEY WORDS: Cadmium $\cdot$ Zinc $\cdot$ Scallops $\cdot$ Biokinetic model $\cdot$ Allometry

\section{INTRODUCTION}

The bioaccumulation of metals in marine invertebrates has received considerable attention over the past few decades (Bryan 1973, Wang \& Fisher 1999, Rainbow 2002, Wang 2003). Marine bivalves can accumulate high concentrations of metals from the ambient environment. As a consequence, they have been widely used as biomonitors of coastal contamination. Much effort has been expended to investigate the mechanisms of metal uptake in different bivalves, including mussels, clams, and oysters (Wang 2003). However, there have been very few studies on scallops (Metian et al. 2007a,b), which are marine bivalves of the family Pectinidae that are widely distributed throughout the world's coastal environments and are important seafood products in many countries, including China. Indeed, scallops were the first living organisms in which cadmium (Cd) was detected (Fox \& Ramage 1931), and they exhibit a high ability to accumulate selected metals, even in unpolluted waters (Viarengo et al. 1993). For example, a range of 7.1 to $321 \mu \mathrm{g} \mathrm{Cd} \mathrm{g}^{-1}$ was found in scallops from different studies (Bustamante \& Miramand 2004). The Antarctic scallops Adamussium colbecki accumulated as much as $100 \mu \mathrm{g} \mathrm{g}^{-1}$ dry weight of $\mathrm{Cd}$ in their digestive glands (Bargagli et al. 1996). Evtushenko et al. (1990) reported that $\mathrm{Cd}$ concentrations in the scallops Mizuhopecten yessoensis increased linearly with the age of scallops from 39 to $400 \mathrm{\mu g} \mathrm{g}^{-1}$ dry weight in the digestive gland, and from 100 to $640 \mu \mathrm{g} \mathrm{g}^{-1}$ dry weight in the kidney. 
Neff (2002) concluded that the arithmetic mean concentrations of $\mathrm{Cd}$ in scallops were the highest among different species of bivalves (clams, mussels, oysters, and scallops).

The concentrations of zinc ( $\mathrm{Zn})$ in scallops are also high, especially in the kidney. Bustamante \& Miramand (2005) reported a range of 313 to $1062 \mu \mathrm{g} \mathrm{g}^{-1}$ dry weight $\mathrm{Zn}$ in the soft tissues of Chlamys varia, whereas the concentrations of $\mathrm{Zn}$ in their kidneys were as high as $38000 \mu \mathrm{g} \mathrm{g}^{-1}$. Such concentrations of $\mathrm{Zn}$ are probably among the highest recorded among any marine organisms thus far. Although it is safe to consume adductor muscle, which is low in trace metals (Metian et al. 2007a), the increasing inputs of industrial, agricultural, and domestic wastes in coastal waters can accelerate the bioaccumulation of metals in scallops, which may subsequently pose health risks to humans due to the consumption of scallops. Furthermore, scallops have been used as sentinel organisms in environmental monitoring (Cranford et al. 2006). Interpretation of the biomonitoring data often requires a clear understanding of the mechanisms of pollutant accumulation. Nevertheless, earlier studies mainly focused on metal uptake from the dissolved phase and the subsequent tissue distribution of metals (Lukyanova et al. 1993). Although a few recent studies have been carried out on the European and tropical Pectinidae (Metian et al. 2007a,b), there is limited information on the dietary accumulation of metals in these important bivalves, especially for the subtropical species. The physiological mechanisms underlying the high $\mathrm{Cd}$ and $\mathrm{Zn}$ concentrations in scallops thus remain a subject of speculation.

One factor affecting metal bioaccumulation is body size, which is the most important biological attribute of an animal. The function of body size, known as allometry, is the most useful predictor of physiological rates (Bartholomew 1981). Despite the prevalence of sizedependent effects, it was not until the 1970s that allometry was recognized in metal ecotoxicology (Boyden 1974). However, a variety of hypotheses or models on the allometry of metal bioaccumulation remain poorly tested (Newman \& Heagler 1990). Even fewer investigations have considered the effects of body size on the basis of different uptake pathways (e.g. dietary and dissolved exposures). The relative importance of different exposure pathways may be related to growth, but again this remains unknown at present.

The bioenergetics-based kinetic model (or biokinetic model) has been used as a powerful tool to investigate the bioaccumulation of metals in aquatic animals (Wang \& Fisher 1996, Luoma \& Rainbow 2005). Three important physiological parameters are required in this model, viz. the metal uptake rate constant from the dissolved phase, the assimilation efficiency (AE) of metal uptake from food, and the metal efflux rate constant from both aqueous and food pathways of uptake. Measurements of these parameters may provide important information for understanding the mechanisms of the high accumulation of metals in the scallops. Earlier studies in marine scallops mainly focused on metal uptake from water, but recent studies have demonstrated that the dietary pathway generally plays an important role in metal accumulation in bivalves (Wang \& Fisher 1996, Chong \& Wang 2001, Ke \& Wang 2001). Assimilation is a complicated and interactive process between the ingested food and the digestive system of the bivalves, in which the quantity/quality of food and the time it takes to process the food (such as the gut passage time; Wang \& Fisher 1996) can significantly affect the assimilation of metals. The metal efflux rate represents the ability of the animals to eliminate metals during the physiological turnover period. Numerous studies have quantified these 3 biokinetic parameters in different bivalves, but few have synthetically considered the size effects on metal bioaccumulation.

In this study, we investigated the effects of body size on metal bioaccumulation in scallops and then employed the biokinetic model to predict the allometry of $\mathrm{Cd}$ and $\mathrm{Zn}$ concentrations. The scallop Chlamys nobilis is an important subtropical and commercial species commonly cultured in southeastern China and widely distributed in East Asia. Currently, there is a strong need to understand the high toxic metal concentrations in several commercially important species of marine bivalves (e.g. oysters and scallops). We separately investigated the allometry of metal uptake rate from the dissolved phase, the dietary $\mathrm{AE}$, and the ingestion rate of scallops. These parameters were then incorporated into the biokinetic model to predict the likely metal concentrations and allometry in scallops, which were then compared to field observations.

\section{MATERIALS AND METHODS}

Collection of experimental organisms and water sampling. Scallops Chlamys nobilis of different sizes were collected from Dapeng Bay (Eastern Hong Kong waters), Guangdong Province, China, and were transported to the laboratory at the Hong Kong University of Science and Technology immediately after collection. Meanwhile, 2 replicates of water samples were collected using acid-cleaned 11 HDPE bottles and kept at $4^{\circ} \mathrm{C}$ in a thermal insulating container, and were shipped to Brooks Rand Labs (USA) within $24 \mathrm{~h}$ for analysis of the total dissolved metals ( $\mathrm{Cd}$ and $\mathrm{Zn}$ ). The trace metal clean technique was used throughout the seawater sampling and analysis. The scallops used for 
measurements of metal body burden were randomly selected and kept frozen at $-80^{\circ} \mathrm{C}$. The scallops used for the bioaccumulation study were carefully cleaned of their epibionts and acclimated in a 601 recirculating seawater aquarium for at least $1 \mathrm{wk}$ prior to the experiments. During the acclimation period, the scallops were fed with the diatom Thalassiosira nordenskioeldii on a daily basis.

Measurement of $\mathrm{Cd}$ and $\mathrm{Zn}$ body burdens. To demonstrate the effects of body size on $\mathrm{Cd}$ and $\mathrm{Zn}$ body burdens in scallops, a total of 148 individuals were analyzed. The body burdens were quantified using the methods described by Blackmore \& Wang (2002). Briefly, the scallops were dissected and the soft tissues were dried at $80^{\circ} \mathrm{C}$ to obtain a constant tissue dry weight, following digestion with concentrated nitric acid ( $70 \%$, Fisher Scientific) at $110^{\circ} \mathrm{C}$ for $3 \mathrm{~d}$ in an autoregulated heating block. The oyster tissue standards (1566a, National Institute of Standards and Technology, Gaithersburg, MD, USA) were digested simultaneously. All completely digested samples were diluted appropriately for quantification of $\mathrm{Cd}$ and $\mathrm{Zn}$ concentrations using HITACHI Z-8100 polarized Zeeman Atomic Absorption Spectroscopy. The method detection limit (MDL) was $0.001 \mu \mathrm{g} \mathrm{\textrm {g } ^ { - 1 }}$ for $\mathrm{Cd}$ and

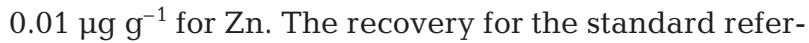
ence materials for $\mathrm{Cd}$ and $\mathrm{Zn}$ was greater than $95 \%$. The metal concentrations in scallops were expressed as $\mu \mathrm{g} \mathrm{g}^{-1}$ dry weight.

Metal uptake from the dissolved phase. A shortterm exposure period was employed to determine the influx rate of the metals (Ke \& Wang 2001). Stable metals $(\mathrm{Cd}$ or $\mathrm{Zn})$ were first added into $0.22 \mu \mathrm{m}$-filtered seawater at concentrations of $0.5,2,10,50,100 \mu \mathrm{g} \mathrm{l}^{-1}$ for $\mathrm{Cd}$, and 2, 10, 50, 100, $200 \mu \mathrm{g} \mathrm{l}^{-1}$ for Zn. Radioisotopes were spiked into the seawater at $3.7 \mathrm{kBq}^{-1}$ for $\mathrm{Cd}$ (corresponding to $33 \mathrm{ng} \mathrm{l}^{-1}$ ), and $7.4 \mathrm{kBq}^{-1}$ for $\mathrm{Zn}$ (corresponding to $0.26 \mathrm{ng} \mathrm{l}^{-1}$ ). The water was equilibrated overnight before the experiments. Each concentration treatment included 6 replicated scallops. Individual scallops of similar sizes (shell height of 20 to $30 \mathrm{~mm}$, dry weight 0.1 to $0.2 \mathrm{~g}$ ) were placed into $200 \mathrm{ml}$ of seawater containing the metals. After $2 \mathrm{~h}$ of exposure, the scallops were removed, rinsed with filtered seawater, and then dissected, and soft tissues as a whole were measured for radioactivity. Afterwards, the tissues were further separated into digestive glands, adductor muscles, gills, and the remaining soft tissues, and the radioactivity in each fraction was assayed to determine the distributions of the metals. The tissues were dried at $80^{\circ} \mathrm{C}$ to obtain the dry weights. The metal influx rate from the dissolved phase (water) $\left(I_{\mathrm{w}}, \mathrm{ng} \mathrm{g}^{-1} \mathrm{~h}^{-1}\right)$ was calculated as:

$$
I_{\mathrm{w}}=\frac{A_{\mathrm{tissue}}}{\mathrm{SA} \times W \times t}
$$

where $A_{\text {tissue }}$ is the radioactivity in the whole soft tissue after exposure (corrected counts per minute, ccpm), SA is the specific activity of the metals in the seawater (ccpm ng ${ }^{-1}$ ), $W$ is the dry weight of the soft tissue $(g)$, and $t$ is the duration of exposure (h).

Another experiment was conducted to determine the influx rate of metals in scallops of different sizes, using the same experimental protocol. The influx rate was measured at 1 fixed metal concentration $\left(0.5 \mu \mathrm{g} \mathrm{l}^{-1}\right.$ for $\mathrm{Cd}$ and $2 \mu \mathrm{g}^{-1}$ for $\mathrm{Zn}$ ), and the radioisotope additions were similar to the concentration experiment.

Metal assimilation efficiency (AE). The AE in bivalves can be measured straightforwardly by the mass balance method in which the bivalves are placed in a gamma counter detector, and the total amount of radioactivity ingested as well as the subsequent loss from the animals can be quantified accurately (Wang \& Fisher 1999). The metal AE was determined as the percentage of initial radioactivity retained in the individual after a period of depuration.

The metal AEs of larger scallops (>35 mm shell height) could not be quantified using the above mass balance method due to the constraint of the detector's size. A ratio method (Calow \& Fletcher 1972, Wang \& Fisher 1996) was therefore used to investigate whether there was a difference in the AE of scallops of different sizes. In this experiment, the diatom Thalassiosira nordenskioeldii was first radiolabeled simultaneously with ${ }^{109} \mathrm{Cd}\left(185 \mathrm{kBq} \mathrm{l}^{-1}\right)$ and ${ }^{65} \mathrm{Zn}\left(111 \mathrm{kBq}{ }^{-1}\right)$ and grown at $14: 10 \mathrm{~h}$ (light:dark) cycles for $3 \mathrm{~d}$. Because the radioisotopes were carried in $0.1 \mathrm{~N} \mathrm{HCl}$ solution, about $20 \mu \mathrm{l}$ of $1 \mathrm{~N} \mathrm{NaOH}$ were added to maintain the seawater $\mathrm{pH}$ at 8.0 after radioisotope addition. On the fourth day, ${ }^{51} \mathrm{Cr}$ (III) was added to the culture at $74 \mathrm{kBq} \mathrm{l}^{-1}$ overnight. After the radiolabeling, the algae were collected by centrifugation $(2180 \times g)$ for $10 \mathrm{~min}$ at $20^{\circ} \mathrm{C}$ and resuspended in $0.22 \mu \mathrm{m}$-filtered seawater. The resuspension was repeated 3 times to minimize desorption of radiotracers into the ambient water during the radioactive feeding. Five replicated subsamples of the radiolabeled diatoms were collected, and the radioactivity of each metal was measured in the cells.

Scallops of different sizes (20 to $40 \mathrm{~mm}$ shell height) were placed in $5 \mathrm{l}$ of $0.22 \mu \mathrm{m}$-filtered seawater. When the scallops opened their shells and began pumping water normally, the radiolabeled diatoms were added at a concentration of $5 \times 10^{4}$ cells $\mathrm{ml}^{-1}$ for $20 \mathrm{~min}$. The food concentration was maintained by further additions at 5 min intervals. After 20 min of pulse feeding, the scallops were rinsed thoroughly with filtered seawater and assayed for their initial radioactivity. Afterwards, the scallops were placed separately into polypropylene beakers (containing $200 \mathrm{ml}$ seawater) held in a 101 enclosed recirculating flow-through aerated seawater aquarium. Nonradioactive algae Thalassio- 
sira nordenskioeldii were fed to the scallops daily at a ration of 1 to $2 \%$ tissue dry weight to promote the depuration of ingested radiolabeled food. The radioactivity in the smallest 17 individuals was counted at frequent time intervals over $60 \mathrm{~h}$. The feces were collected at frequent time intervals over $60 \mathrm{~h}$. The metal AEs were calculated as:

$$
\mathrm{AE}=\left[1-\frac{\left(M /{ }^{51} \mathrm{Cr}\right)_{\text {feces }}}{\left(M /{ }^{51} \mathrm{Cr}\right)_{\text {food }}}\right] \times 100
$$

where $\left(M /{ }^{51} \mathrm{Cr}\right)_{\text {feces }}$ is the ratio of radioactivity of ${ }^{109} \mathrm{Cd}$ or ${ }^{65} \mathrm{Zn}$ to ${ }^{51} \mathrm{Cr}$ in the feces during $24 \mathrm{~h}$ of depuration, and $\left(M /{ }^{51} \mathrm{Cr}\right)_{\text {food }}$ is the ratio of radioactivity of ${ }^{109} \mathrm{Cd}$ or ${ }^{65} \mathrm{Zn}$ to ${ }^{51} \mathrm{Cr}$ in the food particles. The AEs of the 17 smallest scallops were also determined by the mass balance method, i.e. the metal AEs were determined as the percentages of initial radioactivity retained in the scallops after $60 \mathrm{~h}$ of depuration. The scallops were then dissected to determine the metal distributions in different tissues.

Metal efflux in scallops. Metal efflux in scallops following uptake from the dissolved phase and from ingested food was determined using methods described by Wang \& Fisher (1996). In the dietary radiolabeling experiments, the diatoms Thalassiosira nordenskioeldii were radiolabeled $\left(37 \mathrm{kBq} \mathrm{l}{ }^{-1}\right.$ for ${ }^{109} \mathrm{Cd}$, and $37 \mathrm{kBq} \mathrm{l}^{-1}$ for ${ }^{65} \mathrm{Zn}$ ) as described above. The radiolabeled algae were harvested and fed to the scallops at a concentration of $5 \times 10^{4}$ cells m${ }^{-1}$ for $2 \mathrm{~h}$, after which the scallops were transferred to nonradioactive water. This procedure was repeated for $7 \mathrm{~d}$. On the seventh day, all scallops were rinsed and measured for radioactivity, after which they were transferred to a 101 recirculating seawater system containing nonradioactive seawater with aeration for $21 \mathrm{~d}$. The scallops were assayed for radioactivity daily within the first $7 \mathrm{~d}$, and every $3 \mathrm{~d}$ afterwards. The water was renewed every $2 \mathrm{~d}$. Nonradiolabeled $T$. nordenskioeldii were fed to the scallops continuously, at a ration of 1 to $2 \%$ of the tissue dry weights of the scallops.

To measure the metal efflux after uptake from the dissolved phase, the scallops were exposed to radioactive seawater containing $3.7 \mathrm{kBq} \mathrm{l}^{-1}{ }^{109} \mathrm{Cd}$ and $3.7 \mathrm{kBq} \mathrm{l}^{-1}{ }^{65} \mathrm{Zn}$ for $2 \mathrm{~h}$ every day, then transferred to nonradioactive seawater for the remaining $22 \mathrm{~h}$. This procedure was repeated for $7 \mathrm{~d}$ as well. Afterwards, the efflux rate was quantified as described above.

Clearance rate (CR) and growth of the scallops. The CRs in different sizes of scallops were determined using the method described by Ke \& Wang (2001). Briefly, the diatoms Thalassiosira nordenskioeldii were filtered using a $3 \mu \mathrm{m}$ polycarbonate membrane and resuspended in $1 \mathrm{l}$ of $0.22 \mu \mathrm{m}$-filtered seawater containing 1 individual scallop at a cell density of
5000 cell ml ${ }^{-1}$. The algal suspension was maintained by a magnetic stirrer. At time intervals (every $5 \mathrm{~min}$ for $25 \mathrm{~min}$ ), $10 \mathrm{ml}$ of water were sampled, and the cell density was analyzed by a Beckman Coulter Counter. The clearance rate was calculated as:

$$
\mathrm{CR}=\left(\ln C_{0}-\ln C_{t}\right) \times \mathrm{Vol} / t
$$

where CR is the clearance rate of scallops $\left(\mathrm{h} \mathrm{h}^{-1}\right), C_{t}$ is the cell density at time $\mathrm{t}\left(\right.$ cells ml$\left.{ }^{-1}\right), C_{0}$ is the initial cell density at the beginning (cells ml-1 ${ }^{-1}$, Vol is the volume of water $(\mathrm{ml})$, and $t$ is the duration of the experiment.

The growth rate of scallops was measured by hanging a group of scallops in Dapeng Bay using a 10-layer net cage. The whole cage was $1.5 \mathrm{~m}$ in height and deployed at a depth of $2 \mathrm{~m}$ (from the top of the cage to the surface). Thirty individuals with an initial shell height of 20 to $30 \mathrm{~mm}$ were placed in each layer for 5 mo. Each month, 12 scallops were randomly selected from each layer and their dry weights were measured. The specific growth rate was calculated by slope of the regression between natural log of dry weight and time.

Kinetic modeling of metal bioaccumulation. Metal bioaccumulation in the scallops can be determined by the following biokinetic equation (Wang et al. 1996):

$$
\frac{\mathrm{d} C}{\mathrm{~d} t}=k_{\mathrm{u}} \times C_{\mathrm{w}}+\mathrm{AE} \times \mathrm{IR} \times C_{\mathrm{f}}-\left(k_{\mathrm{e}}+g\right) \times C
$$

where $C$ is the metal concentration in the scallops at time $t_{1} k_{\mathrm{u}}$ is the metal uptake rate constant from the dissolved phase $\left(\mathrm{l} \mathrm{g}^{-1} \mathrm{~d}^{-1}\right), C_{\mathrm{w}}$ is the metal concentration in the ambient water $\left(\mu \mathrm{g} \mathrm{l}^{-1}\right)$, and $\mathrm{AE}$ is the metal assimilation efficiency. IR is the ingestion rate $\left(\mathrm{g} \mathrm{g}^{-1}\right.$ $\left.\mathrm{d}^{-1}\right), C_{\mathrm{f}}$ is the metal concentration in the ingested food particles $\left(\mu \mathrm{g} \mathrm{g}^{-1}\right)$ and equals the metal concentration factor (CF) in the ingested food particles multiplied by $C_{\mathrm{w}}, k_{\mathrm{e}}$ is the metal efflux rate constant $\left(\mathrm{d}^{-1}\right)$, and $g\left(\mathrm{~d}^{-1}\right)$ is the growth rate. Under steady-state condition $\left(\frac{\mathrm{d} C}{\mathrm{~d} t}=0\right)$, the body concentration of metals in the scallops $\left(C_{\mathrm{ss}}\right)$ is calculated as:

$$
C_{\mathrm{ss}}=\frac{k_{\mathrm{u}} \times C_{\mathrm{w}}}{k_{\mathrm{ew}}+g}+\frac{\mathrm{AE} \times \mathrm{IR} \times C_{\mathrm{f}}}{k_{\mathrm{ef}}+g}
$$

where $k_{\text {ew }}$ is the efflux rate following uptake from the dissolved phase and $k_{\text {ef }}$ is the efflux rate following dietary uptake. The fraction of uptake from the dissolved phase $(R)$ can be calculated from the following equation (Ke \& Wang 2001):

$$
R=\frac{k_{\mathrm{u}}}{\left(k_{\mathrm{u}}+\mathrm{AE} \times \mathrm{IR} \times K d\right)}
$$

where $K d$ is the partitioning coefficient of the metals (or $\mathrm{CF}$ ) in suspended particles. 
The weight-specific physiological kinetic parameters $(y)$ are considered as a power function of the tissue dry weight $(W$, in $g)$ :

$$
y=a \times W^{b}
$$

where $y$ represents $k_{\mathrm{u}}, \mathrm{AE}$, or IR, and $b$ is the allometric coefficient. When $b>0(b<0)$, kinetic parameters are positively (negatively) correlated with body size, when $b=0$, the kinetic parameters are independent of body size.

Radioactivity measurements and statistical analysis. The radioactivity was measured using a Wallac $1480 \mathrm{NaI}$ (T1) gamma counter. All counts were related to standards and spillover. The gamma emission of ${ }^{109} \mathrm{Cd}$ was determined at $88 \mathrm{keV},{ }^{65} \mathrm{Zn}$ at $1115 \mathrm{keV}$, and ${ }^{51} \mathrm{Cr}$ at $260 \mathrm{keV}$. Counting times were adjusted to yield a propagated counting error of less than $5 \%$. The statistical significance of the power regression between body size and other parameters was also tested by analysis of variance (ANOVA), and the regression was quantified by the coefficient of determination, $\mathrm{r}^{2}$.

\section{RESULTS AND DISSCUSSION}

\section{Allometry of Cd and Zn body burdens in scallops}

The tissue concentrations of $\mathrm{Cd}$ and $\mathrm{Zn}$ in scallops of different sizes are shown in Fig. 1. The body concentrations of $\mathrm{Cd}$ and $\mathrm{Zn}$ were described as a power function of tissue dry weight: $\mathrm{Cd}=10.3 W^{-0.266}(\mathrm{p}<0.0001)$, and $\mathrm{Zn}=184.7 W^{-0.252}(\mathrm{p}<0.0001)$. High concentrations of Cd were found in Chlamys nobilis, i.e. 7.6 to $30.8 \mu \mathrm{g} \mathrm{g}^{-1}$ dry weight over a size range of 0.04 to $0.9 \mathrm{~g}$ dry weight. Bustamante \& Miramand (2004) also reported similarly high Cd levels in scallops from the North Atlantic waters (5.7 to $38.7 \mu \mathrm{g} \mathrm{g}^{-1}$ ). Such ranges of $\mathrm{Cd}$ concentrations were probably among the highest found among different bivalve species. For example, the highest $\mathrm{Cd}$ concentration in the soft tissues of oys- ters and mussels measured by the US National Status and Trends Program was only $5.7 \mu \mathrm{g} \mathrm{g}^{-1}$ dry weight (Neff 2002). The Zn concentrations in our scallops (126.5 to $579.1 \mathrm{\mu g} \mathrm{g}^{-1}$ ) were comparable to the results found in some other scallop species in North Atlantic waters, where a range of 235 to $437 \mathrm{\mu g} \mathrm{g}^{-1} \mathrm{Zn}$ has been reported (Bustamante \& Miramand 2004). However, these $\mathrm{Zn}$ values were lower than those in oysters, which have a high ability to accumulate Zn (e.g. up to $28000 \mu \mathrm{g} \mathrm{g}^{-1} \mathrm{Zn}$ in Crassostrea virginica, Neff 2002), but were higher than those generally found in mussels (Neff 2002). Variation in metal body burden was also obvious in our study. A 2-fold difference in body concentrations was found in scallops of similar sizes. Bioaccumulation is a complex process influenced by multiple routes of exposure (waterborne or dietary) and geochemical effects on bioavailability (Luoma \& Rainbow 2005). A variable pattern of accumulation does exist within and among species and is an interesting issue to be explored further.

The decrease of weight-specific trace element content with body size has been found in a variety of animals (Boyden 1974). The coefficients of the power function found in our study were -0.266 for $\mathrm{Cd}$ and

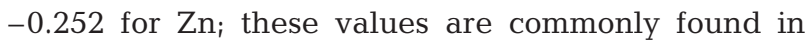
many metabolic functions of body size (Peters 1983).

\section{Metal uptake from the dissolved phase}

A log-log linear relationship between the uptake rate and the ambient dissolved metal was observed in scallops with a shell height of 20 to $30 \mathrm{~mm}$ (Fig. 2), consistent with numerous measurements in other marine bivalves (Bjerregaard \& Depledge 1994, Wang 2003). The power coefficient for $\mathrm{Cd}$ (1.016) was close to 1 , but it was less than 1 for $\mathrm{Zn}$ (0.860). The uptake rate constant $\left(k_{\mathrm{u}}\right)$, calculated by the influx rate divided by the metal concentration in the dissolved phase, was significantly affected by the body size (Fig. 2). The allometric coefficient of the power function of the metal influx rate and tissue dry weight was -0.259 for $\mathrm{Cd}$ and -0.266 for $\mathrm{Zn}$. A decreasing allometric relationship between the influx rate of metals and the tissue dry weight was often found in marine bivalves (Lee et al. 1998, Chong \& Wang 2001). The linear relationship between the influx rate and the dissolved metal concentration suggests that metal uptake is passively facilitated rather than actively regulated. Thus, the size effects on waterborne metal uptake can be explained by a general observation that both the weight-specific gill
Fig. 1. Chlamys nobilis. (a) Cd and (b) Zn concentrations as a function of tissue dry weights. Each dot represents 1 individual scallop $(\mathrm{n}=148)$ 
a

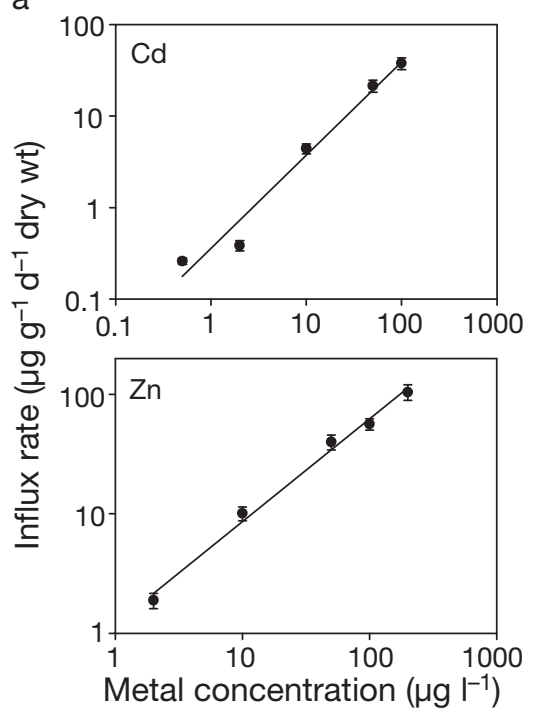

b
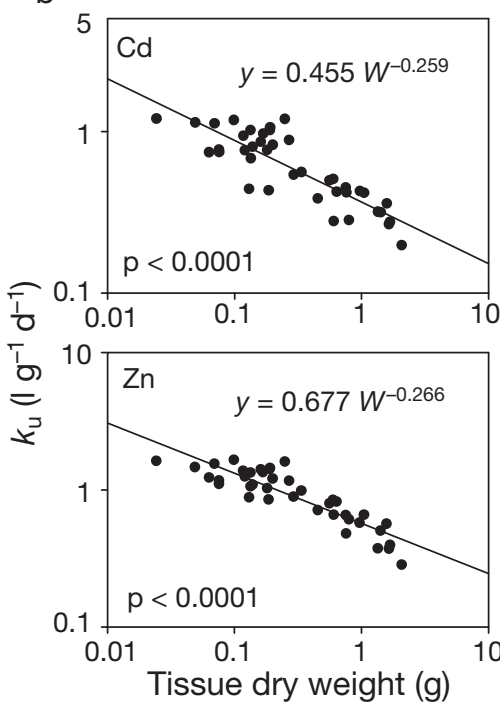

Fig. 2. Chlamys nobilis. (a) Influx rates (mean $\pm \mathrm{SD}$ ) of $\mathrm{Cd}$ and $\mathrm{Zn}$ into scallops (20 to $30 \mathrm{~mm}$ shell height) at different ambient metal concentrations ( $\mathrm{n}=6)$. Relationships between metal influx rate $\left(I_{\mathrm{w}}, \mathrm{gg} \mathrm{g}^{-1} \mathrm{~d}^{-1}\right)$ and metal concentration in the dissolved phase $\left(C_{\mathrm{w}}, \mu \mathrm{g} \mathrm{l^{-1 }}\right)$ in the scallops are as follows: Cd: $I_{\mathrm{w}}=$ $0.359 C_{\mathrm{w}}{ }^{1.016 \pm 0.101}\left(\mathrm{r}^{2}=0.971, \mathrm{p}<0.001\right), \mathrm{Zn}: I_{\mathrm{w}}=1.186 C_{\mathrm{w}}{ }^{0.860 \pm 0.044}\left(\mathrm{r}^{2}=0.992, \mathrm{p}<\right.$ 0.001). (b) Calculated uptake rate constants $\left(k_{\mathrm{u}}\right)$ of $\mathrm{Cd}$ and $\mathrm{Zn}$ in relation (log$\log$ ) to the tissue dry weights. Each dot represents 1 individual scallop ( $\mathrm{n}=40$ )

surface area to volume ratio and the pumping rate decrease with increasing body dry weight in bivalves (Jones et al. 1992). However, the decreasing trend is not always observed for all metals or bivalves. For example, $\mathrm{Cr}$ and $\mathrm{Zn}$ uptake in the clam Potamocorbula amurensis was not significantly related to the body size of clams (Lee et al. 1998).

Compared to those in other bivalves, the uptake rate constants $\left(k_{\mathrm{u}}\right)$ of scallops were typically higher than those in clams (Macoma balthica, $\sim 0.20 \mathrm{~g}$ dry weight, $0.032 \mathrm{l} \mathrm{g}^{-1} \mathrm{~d}^{-1}$ for $\mathrm{Cd}, 0.091 \mathrm{l} \mathrm{g}^{-1} \mathrm{~d}^{-1}$ for Zn, Ruditapes philippinarum, 0.25 0.35 g dry weight, $0.064 \mathrm{l} \mathrm{g}^{-1} \mathrm{~d}^{-1}$ for

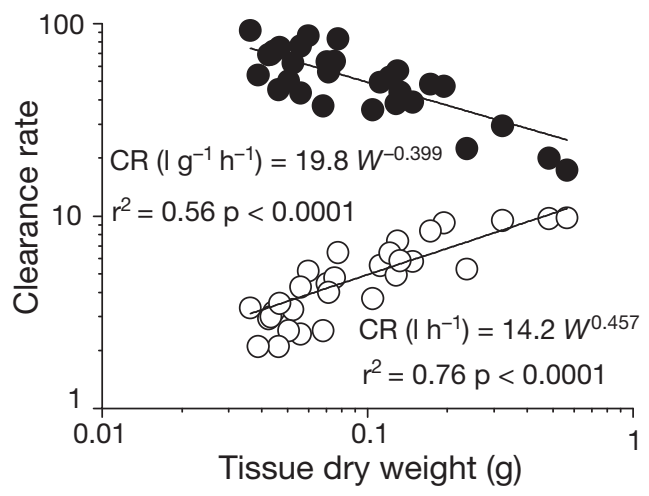

Fig. 3. Chlamys nobilis. Individual (O) and weight-specific $(\bullet)$ clearance rates (CR) of scallops in relation to tissue dry weights $(W)$. Each dot represents 1 individual scallop $(\mathrm{n}=30)$
Cd, $0.234 \mathrm{l} \mathrm{g}^{-1} \mathrm{~d}^{-1}$ for $\mathrm{Zn}$; Wang 2003). The high weight-specific filtration rates of the scallops in our study, which similarly decreased with body size (Fig. 3), may partially explain this inter-species difference, because metal influx rate could be affected by the volume of water processed by the gills of the organisms (Lee et al. 1998). Wang (2001) suggested that $k_{\mathrm{u}}$ was positively correlated with the filtration rates of different species of marine bivalves. However, within a single species of bivalve, the filtration rate is not important in controlling the individual variation in metal uptake.

\section{Metal uptake from the dietary phase}

The retention of $\mathrm{Cd}$ and $\mathrm{Zn}$ in the smallest 17 scallops following ingestion of radiolabeled diatoms is shown in Fig. 4. There was a major decrease of both metals within the first $12 \mathrm{~h}$, after which the retention of $\mathrm{Cd}$ remained relatively constant, whereas Zn maintained a pattern of slight decrease. The calculated AEs of $\mathrm{Cd}$ and Zn were $80.6 \pm 9.0 \%$ and $67.5 \pm 6.8 \%$, respectively.

The AEs of $\mathrm{Cd}$ and $\mathrm{Zn}$ in scallops of different sizes were measured using the ratio method. Over $90 \%$ of unassimilated $\mathrm{Cd}$ and $\mathrm{Cr}$ were egested within the first $12 \mathrm{~h}$, and the fraction retained in the bodies of the scallops became stable afterwards (Fig. 5). The egestion of Zn was continuous throughout the $60 \mathrm{~h}$, and a 2-phase egestion pattern was evident. After $60 \mathrm{~h}$, the ${ }^{51} \mathrm{Cr}$ (III) remaining in the soft tissue of the 11 smallest individuals was 5 to $11 \%$ (with an average of $7 \%$ ), indicating that $\mathrm{Cr}$ (III) was also slightly assimilated by the scallops.

We calculated the AE using the total feces collected within the first $24 \mathrm{~h}$ by the ratio method. The AEs (with the assumption that Cr was inert to the scallops) were significantly and positively correlated with the body size ( $b=0.0474$ for $\mathrm{Cd}$ and 0.0563 for $\mathrm{Zn}$, Fig. 3). The $\mathrm{AE}$ of $\mathrm{Cd}$ climbed from $70 \%$ in the smallest individuals to $97 \%$ in the largest individuals, indicating a strong assimilation capacity for $\mathrm{Cd}$ in scallops. A similar trend was also found for the AE of Zn versus body size, which increased from 69 to $86 \%$ with increasing body size. The AEs of Cd calculated from the ratio method (84.2 \pm $7.8 \%$ ) were comparable to those calculated from the mass balance method $(80.6 \pm 9.0 \%)$. However, the AEs of $\mathrm{Zn}$ calculated by the ratio method $(76.0 \pm 6.7 \%)$ were slightly (albeit not significantly) higher than those calculated by the mass balance method $(67.5 \pm$ $6.8 \%$ ). 

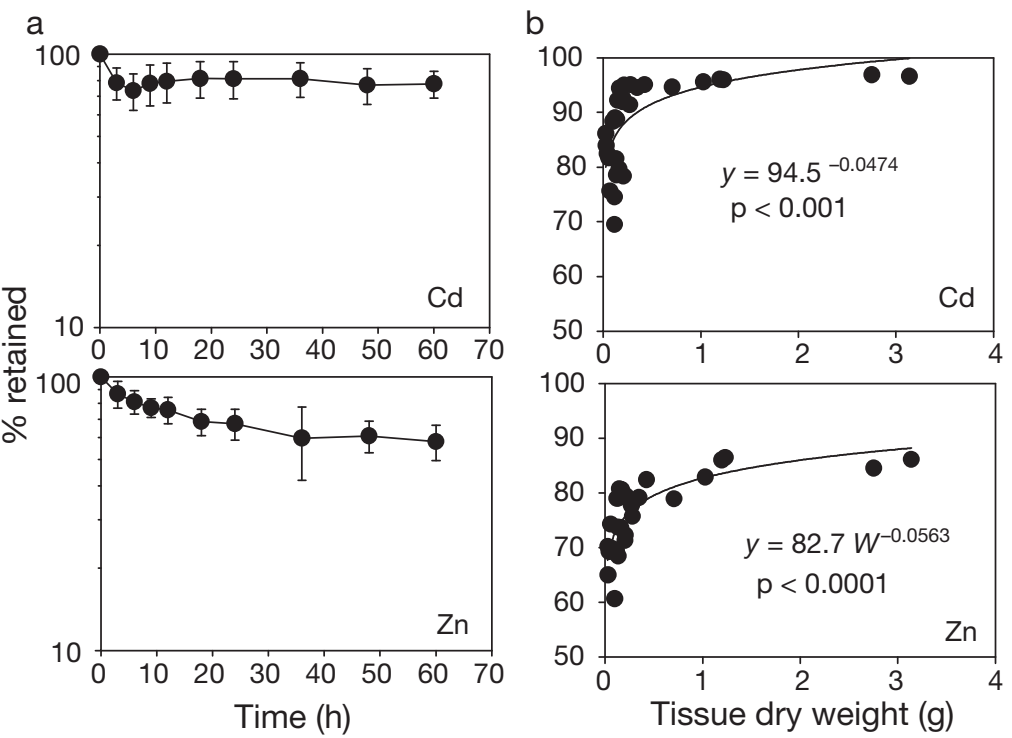

Fig. 4. Chlamys nobilis. (a) Depuration (mean $\pm \mathrm{SD}$ ) of Cd and Zn from scallops following a pulse feeding of radiolabeled algae $(\mathrm{n}=17)$. (b) Assimilation efficiencies of $\mathrm{Cd}$ and $\mathrm{Zn}$ in relation to tissue dry weights $(W)$, measured by the dual ratio method $(\mathrm{n}=24)$
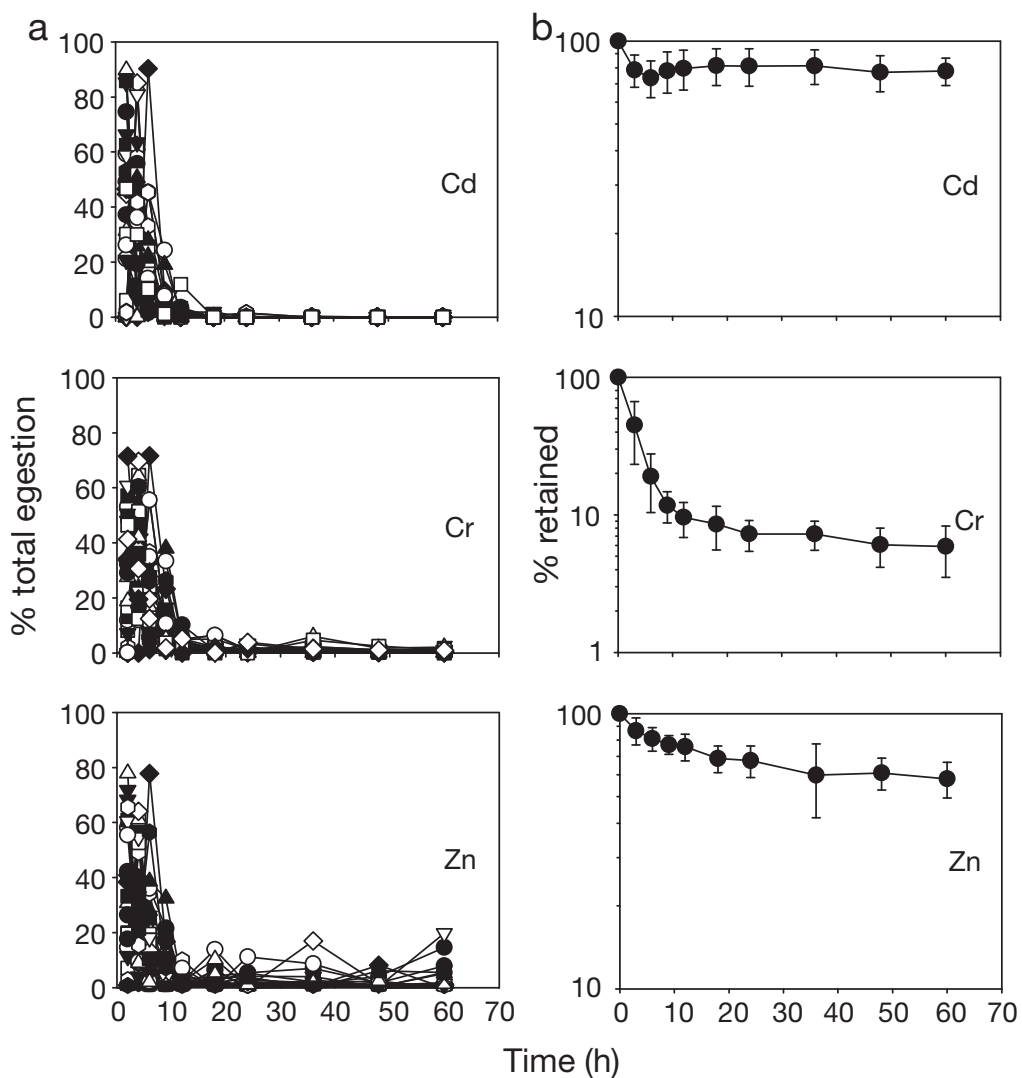

Fig. 5. Chlamys nobilis. (a) Instantaneous egestion rates of $\mathrm{Cd}, \mathrm{Cr}$, and $\mathrm{Zn}$ in 24 scallops (20 to $45 \mathrm{~mm}$ in shell height) during the depuration period; diffferent symbols represent individual scallop. (b) Metal retention of the 17 smallest scallops (20 to $25 \mathrm{~mm}$ in shell height, 0.1 to $0.2 \mathrm{~g}$ dry weight) over $60 \mathrm{~h}$ of depuration
Metal AE was typically determined by the mass balance method when the total amount of initial ingested metals was known. However, due to the size limitations of the gamma detector, we were unable to measure the AE in large scallops using this method. Instead, we used the dual tracer ratio method to determine the metal AEs in scallops of different sizes, with the assumption that $\mathrm{Cr}$ (III) was inert (unassimilated) in the individuals. The AEs of Cd determined by the ratio method were comparable to those determined directly by the mass balance method, suggesting that the ratio method can be used to determine the metal AEs for large individuals when the size of the gamma detector becomes a limiting factor. It is possible that a higher AE may be attained when measured by the ratio method. First, the $\mathrm{Cr}$ (III) was slightly bioavailable to the scallops $(\mathrm{AE}=7 \%$, which may lead to an overestimate of the metal AE when calculated by the ratio method. Second, one important assumption for the ratio method is that the rates of metal releases from feces into the dissolved phase should be similar (Wang \& Fisher 1999). This assumption may not be easily met for different metals given their different binding to feces. It is also difficult to recover all of the fine feces produced by small scallops.

The AEs of Cd in the scallops measured in our study were comparable (using algae as food) to those found in the scallops Chlamys varia (>86\%) and Pecten maximus ( $>80 \%$; Metian et al. 2007b) and the clams Macoma balthica (88\% for $\mathrm{Cd}$ and $50 \%$ for $\mathrm{Zn}_{\text {; }}$ Lee et al. 1998). However, the scallops tended to assimilate $\mathrm{Cd}$ and Zn more efficiently than the clam Ruditapes philippinarum, mussels, and oysters. For example, the AEs ranged from 22 to $55 \%$ for $\mathrm{Cd}$ and 29 to $59 \%$ for $\mathrm{Zn}$ in $R$. philippinarum, and 11 to $25 \%$ for $\mathrm{Cd}$ and 21 to $36 \%$ for $\mathrm{Zn}$ in the green mussel Perna viridis (Chong \& Wang 2000). Our results showed that the AEs of both $\mathrm{Cd}$ and $\mathrm{Zn}$ were positively correlated with the body size of the scallops, indicating more efficient digestion and assimilation in larger individuals. One possible explanation for the remarkable ability of scallops to assimilate metals from food is their longer food gut retention time compared 
to other bivalves, leading to a longer effective time for enzymatic attack and absorption of digested products. Retaining food for long periods may be a digestive strategy of this species (Brillant \& MacDonald 2000).

\section{Metal efflux and growth dilution}

The depuration of metals from the scallops following $7 \mathrm{~d}$ of exposure to radiolabeled food and water is shown in Fig. 6. Compartmental analysis of the metal efflux pattern is given in Table 1. More Cd than Zn was retained in the scallops after $21 \mathrm{~d}$ of depuration. Generally, the metal loss after uptake from the dissolved phase and dietary phase could be described by a 2compartmental loss, which has also been observed in a previous study (Metian et al. 2007b). The efflux rate constant, calculated from the second compartment (10 to $21 \mathrm{~d}$ ), was $0.005 \mathrm{~d}^{-1}$ for $\mathrm{Cd}$ and $0.012 \mathrm{~d}^{-1}$ for $\mathrm{Zn}$ when the metals were accumulated from the dissolved phase. When the metals were accumulated from the dietary phase, the efflux rate constants were $0.009 \mathrm{~d}^{-1}$ for $\mathrm{Cd}$ and $0.023 \mathrm{~d}^{-1}$ for $\mathrm{Zn}$.

The efflux rates of $\mathrm{Cd}\left(0.005\right.$ to $\left.0.009 \mathrm{~d}^{-1}\right)$ in scallops were lower compared to those in most other bivalves,

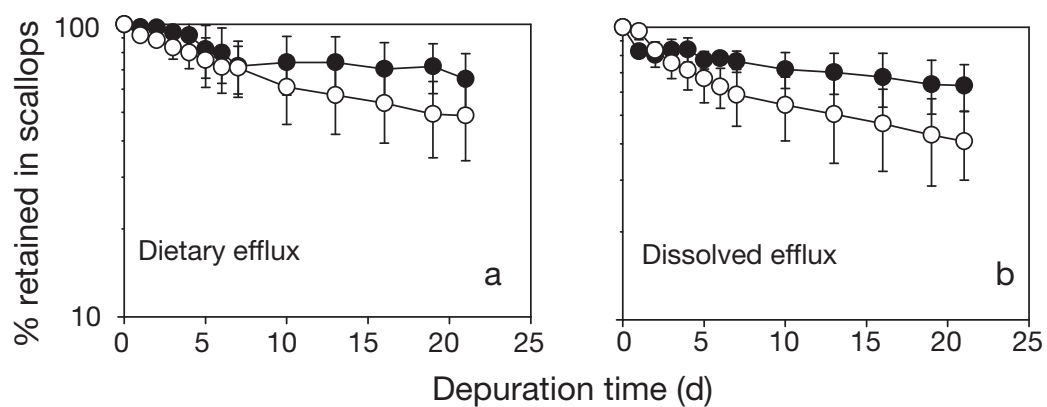

Fig. 6. Chlamys nobilis. Depuration (mean $\pm \mathrm{SD}$ ) of $\mathrm{Cd}(--)$ and $\mathrm{Zn}(-\mathrm{o})$ from the scallops following $7 \mathrm{~d}$ of uptake of $\mathrm{Cd}$ and $\mathrm{Zn}$ from the (a) dietary phase or (b) dissolved phase $(n=5)$

Table 1. Chlamys nobilis. Compartmental analysis of metal depuration in scallops following uptake from the dissolved and dietary phases. Mean $\pm \operatorname{SD}(n=5)$. $k_{\mathrm{e}}$ : metal efflux rate constant

\begin{tabular}{|lcccc|}
\hline Source of metal & Metal & $\begin{array}{c}\text { Depuration } \\
\text { compartment }(\mathrm{d})\end{array}$ & $\begin{array}{c}\text { Percentage in } \\
\text { compartment }\end{array}$ & $k_{\mathrm{e}}\left(\mathrm{d}^{-1}\right)$ \\
\hline Dissolved phase & $\mathrm{Cd}$ & $0-7$ & $23.5 \pm 6.4$ & $0.026 \pm 0.007$ \\
& & $10-21$ & $76.5 \pm 6.4$ & $0.005 \pm 0.003$ \\
& $\mathrm{Zn}$ & $0-7$ & $41.2 \pm 12.9$ & $0.056 \pm 0.021$ \\
& & $10-21$ & $58.8 \pm 12.9$ & $0.012 \pm 0.006$ \\
Dietary phase & $\mathrm{Cd}$ & $0-7$ & $28.0 \pm 15.7$ & $0.036 \pm 0.027$ \\
& & $10-21$ & $72.0 \pm 15.7$ & $0.009 \pm 0.001$ \\
& $\mathrm{Zn}$ & $0-7$ & $25.8 \pm 9.6$ & $0.054 \pm 0.013$ \\
& & $10-21$ & $74.2 \pm 9.6$ & $0.023 \pm 0.014$ \\
\hline
\end{tabular}

while the efflux rates of $\mathrm{Zn}$ were comparable to those in other bivalves (Perna viridis: $0.020 \mathrm{~d}^{-1}$ for $\mathrm{Cd}, 0.029 \mathrm{~d}^{-1}$ for $\mathrm{Zn}$; Macoma balthica: $0.018 \mathrm{~d}^{-1}$ for $\mathrm{Cd}, 0.012 \mathrm{~d}^{-1}$ for $\mathrm{Zn}$; Ruditapes philippinarum: $0.010 \mathrm{~d}^{-1}$ for $\mathrm{Cd}, 0.023 \mathrm{~d}^{-1}$ for $\mathrm{Zn}$; Crassostrea rivularis: $0.014 \mathrm{~d}^{-1}$ for $\mathrm{Cd}, 0.014 \mathrm{~d}^{-1}$ for $\mathrm{Zn}$; Saccostrea glomerata: $0.004 \mathrm{~d}^{-1}$ for $\mathrm{Cd}, 0.003 \mathrm{~d}^{-1}$ for $\mathrm{Zn}$; Wang 2003). The lower efflux rate of $\mathrm{Cd}$ shows the lack of an effective mechanism to regulate the concentrations of $\mathrm{Cd}$ in contrast to $\mathrm{Zn}$ in scallops. Given the high concentration of $\mathrm{Cd}$ in scallops, there should be some effective mechanisms for preventing the toxic effect in the animals. Metallothionein in the digestive gland may be responsible for the detoxification of $\mathrm{Cd}$ and makes the metals not toxic to scallops (Viarengo et al. 1993). In our study, nearly $80 \%$ of Cd was distributed in the digestive glands after uptake from food. A similar result was reported by Uthe \& Chou (1987), i.e. $91 \%$ of Cd was contained in the digestive glands of the sea scallop Placopecten magellanicus. Earlier studies on scallops mainly focused on the binding of metals to metallothionein (Stone et al. 1986, Evtushenko et al. 1990, Viarengo et al. 1993), a low molecular weight, high-sulfur protein that strongly binds to metals and reduces their ionic forms in the cytoplasm. Other studies indicated sequestration of metals into insoluble forms leading to non-toxic effects in Pectinidae, which may partially explain the low efflux rate in scallops in our study. For example, $\mathrm{Cd}$ was mainly stored in insoluble forms in Chlamys varia (George 1980 et al.). Fowler \& Gould (1988) concluded that the effective sequestration of $\mathrm{Cd}$ within kidney concretions and cytosolic metal-binding protein compartments explained the lack of $\mathrm{Cd}$ toxicity in scallops. However, metallothionein alone may not explain the low efflux rate of $\mathrm{Cd}$ in scallops. Although the body concentration of $\mathrm{Cd}$ is poorly regulated, those of certain essential metals, such as $\mathrm{Mg}$, Zn, and $\mathrm{Cu}$, are better regulated (Bryan 1973, Gould et al. 1988, Lukyanova et al. 1993). We did not measure the efflux rates of scallops of different sizes due to the size limitation of the gamma counter detector, but efflux rate constants are usually independent of body size of the individuals (Lee et al. 1998, Zhang \& Wang 2007). In marine bivalves, efflux rates appear to be relatively constant among both different metals and species (Reinfelder et al. 1998).

Growth of scallops in the field measured over a period of 5 mo is shown in 


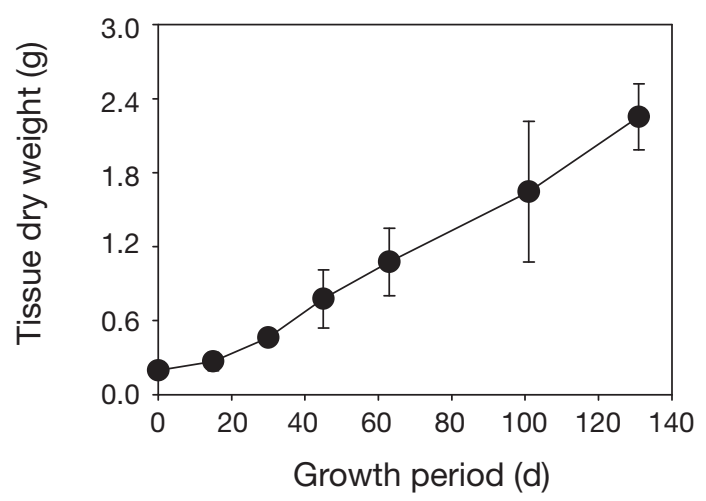

Fig. 7. Chlamys nobilis. Growth (mean $\pm \mathrm{SD}$ ) within a period of $131 \mathrm{~d}(\mathrm{n}=12)$

Fig. 7 , and the calculated growth rate constant was $0.019 \mathrm{~d}^{-1}$. The importance of growth dilution has not usually been addressed in model forecasts (Reinfelder et al. 1998). However, growth can be ignored only when it is much smaller than the efflux rate constant. The growth dilution can become a significant factor in trace element trophic transfer and bioaccumulation in smaller organisms and in adult organisms (such as bivalves) that experience changes in tissue mass related to their reproductive cycles (Reinfelder et al. 1998). Growth in our study was 67.9 to $79.2 \%$ and 45.2 to $61.3 \%$ of the overall efflux rate of $\mathrm{Cd}$ and $\mathrm{Zn}$, respectively. Thus, it is a key parameter that greatly affected the body burdens in scallops.

\section{Kinetic modeling of metal bioaccumulation}

To apply the biokinetic model, the values of $k_{\mathrm{u}}$ AE, and $k_{\mathrm{e}}$ were taken from this study. The CRs in our study were also determined using a pure diatom diet. Considering the great variation of ingestion rates of scallops in natural populations as influenced by food quality/quantity and physical conditions (e.g. flow rate and temperature, MacDonald \& Thompson 1986), it is misleading to directly apply the laboratory-determined ingestion rate in the model. Cranford \& Gordon (1992) found that the same individual scallops Placopecten magellanicus filtered algal cells Tetraselmis sueica 3 times faster than they filtered natural seston particles. We, therefore, calculated the CRs of scallops in the field by multiplying our results by a factor of 0.33. A typical suspended particle concentration of $3.5 \mathrm{mg} \mathrm{l}^{-1}$ in Dapeng Bay waters (where the scallops were collected for this study) was used in the calculation (EPD 2005). The ingestion rate is the combination of the $\mathrm{CR}$ and seston concentration. The measured total dissolved metal concentrations were 0.063 and $0.57 \mu \mathrm{g} \mathrm{l}^{-1}$ for $\mathrm{Cd}$ and $\mathrm{Zn}$, respectively, which were within the range of available data recorded in Hong Kong coastal waters ( Ng \& Wang 2005). Because of the lack of field measurements of $\mathrm{Cd}$ and $\mathrm{Zn}$ concentrations in the food particles, we used $K d$ values for each metal to calculate the metal concentration in seston. However, the $K d$ can vary considerably in the field, for example, 3900 to 10500 for Cd and 3600 to 35000 for Zn (Fisher et al. 2000). A range of 1000 to 20000 for $\mathrm{Cd}$ and 10000 to 200000 for $\mathrm{Zn}$ was also reported in the literature (Ke \& Wang 2001). We chose a median value of Kd of 10000 and 50000 for $\mathrm{Cd}$ and $\mathrm{Zn}$ in our modeling calculation. A summary of each parameter is shown in Table 2.

Using Eq. (6), the predicted fractions of $\mathrm{Cd}$ and $\mathrm{Zn}$ uptake from the dissolved phase increase slightly with body size and then level off in larger scallops. Overall, the dissolved uptake plays a much less important role in the overall metal accumulation $(<20 \%)$, especially for $\mathrm{Zn}(<10 \%)$. These calculations suggest that diet is the dominant pathway in metal bioaccumulation in scallops. The predicted metal concentration decreases with an increase of tissue dry weight (Fig. 8), similar to the measured metal concentrations in the scallops (Fig. 1). The predicted allometric coefficient $b$ is -0.342 for $\mathrm{Cd}$ and -0.339 for $\mathrm{Zn}$, which is close to the measured $b(-0.266$ for $\mathrm{Cd}$, -0.252 for $\mathrm{Zn}$ ) in the scallops (Fig. 8). The successful prediction implies that the biokinetic model can be used in risk assessment or aquaculture. With the available key parameters $\left(k_{\mathrm{u}}, \mathrm{AE}, k_{\mathrm{e}}\right.$ and $\left.g\right)$, the bioaccumulation of metals in the animals of different size groups can be predicted under a series of estimated metal concentrations in a selected area.

Table 2. Chlamys nobilis. Parameters used in the biokinetic model to predict the accumulation of $\mathrm{Cd}$ and $\mathrm{Zn}$ in the scallops. $k_{\mathrm{ef}}$ : efflux rate following uptake from food; $k_{\text {ew }}$ : efflux rate following uptake from water; $K d$ : partitioning coefficients of the metals; $W$ : dry weight of the soft tissue

\begin{tabular}{|lcc|}
\hline & $\mathrm{Cd}$ & $\mathrm{Zn}$ \\
\hline Assimilation efficiency & $0.945 W^{-0.0474}$ & $0.827 W^{-0.0563}$ \\
Dissolved uptake constant $\left(\mathrm{l} \mathrm{g}^{-1} \mathrm{~d}^{-1}\right)$ & $0.455 W^{-0.259}$ & $0.677 W^{-0.266}$ \\
Ingestion rate $\left(\mathrm{g} \mathrm{g}^{-1} \mathrm{~d}^{-1}\right)$ & $0.416 W^{-0.399}$ & $0.416 W^{-0.399}$ \\
$k_{\text {ef }}\left(\mathrm{d}^{-1}\right)$ & 0.009 & 0.023 \\
$k_{\text {ew }}\left(\mathrm{d}^{-1}\right)$ & 0.005 & 0.012 \\
Growth rate $\left(\mathrm{d}^{-1}\right)$ & 0.019 & 0.019 \\
Total dissolved metal concentration & $0.063 \pm 0.018$ & $0.57 \pm 0.22$ \\
$\left(\mu g \mathrm{l}^{-1}\right)$, mean $\pm \mathrm{SD}$ & 10000 & 50000 \\
$K d\left(\mathrm{~kg}^{-1}\right)$ & & \\
\hline
\end{tabular}




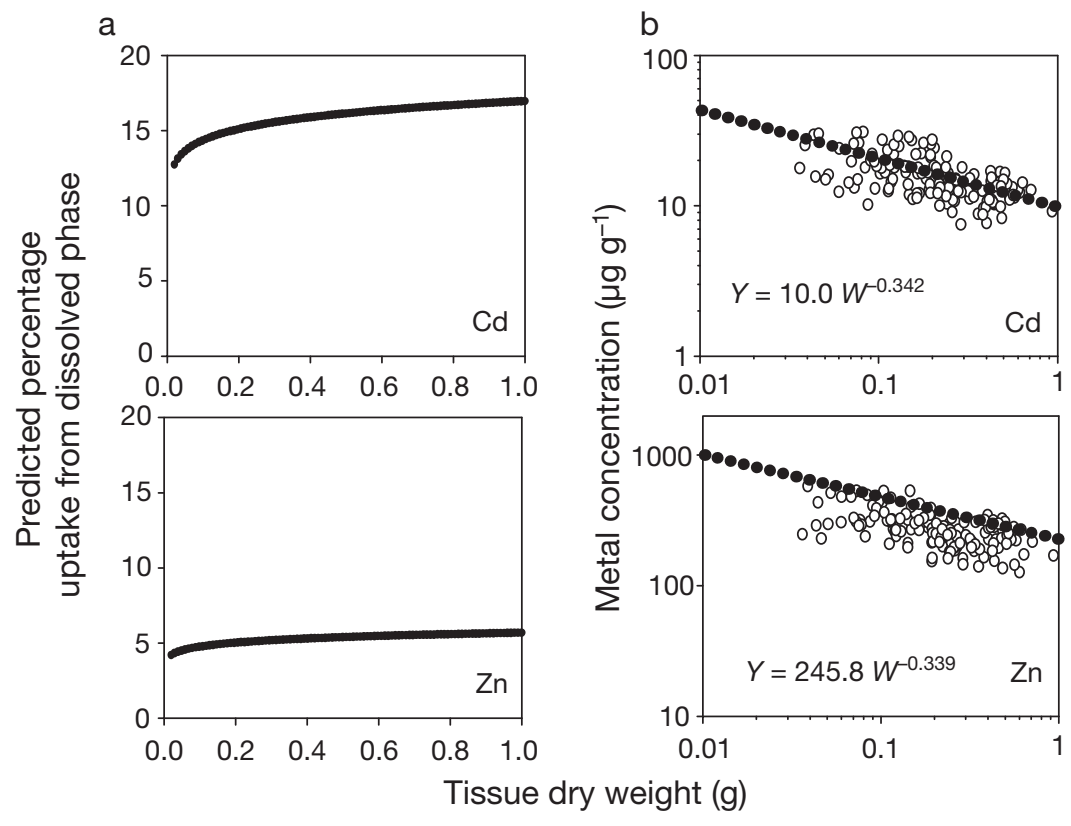

Fig. 8. Chlamys nobilis. (a) Predicted percentage of uptake from the dissolved phase in relation to tissue dry weight. (b) Comparison between the predicted ( and measured $(\mathrm{O})$ metal concentrations in the scallops

kinetic model can also predict the allometric effects on metal body burden in marine bivalves. Uptake from the dissolved and dietary pathways, efflux, and growth are all responsible for the overall metal accumulation in marine invertebrates. Although AE increased with body size, the decreasing patterns of waterborne metal uptake and ingestion rate as well as growth dilution counteract this effect and eventually lead to the decrease of $\mathrm{Cd}$ and $\mathrm{Zn}$ body burdens in scallops. However, the decrease of weight-specific ingestion rate in larger scallops contributes predominantly to the lower metal concentration because the dietary route plays a more important role in metal accumulation. Similar results have also been found in marine fish (Zhang \& Wang 2007), indicating the practicability of biokinetic models in both marine invertebrates and fish. Food intake in scallops is a complex

Metal accumulation in market-sized animals is still a matter of concern under increasing coastal environmental pollution. The predicted metal concentrations (10.0 $W^{-0.342}$ for $\mathrm{Cd}$ and $245.8 W^{-0.339}$ for $\mathrm{Zn}$ ) were also comparable to the measured ones (Fig. 8), although the predicted $\mathrm{Zn}$ concentrations were slightly higher $(33 \%)$. This may be due to the scallops' ability to regulate the essential metals in their bodies (Bryan 1973) under different conditions. However, we also noticed some potential problems in the modeling forecasts. First, instead of direct measurements of metal concentrations in the food, we used the metal $K d$, which can vary under different environmental conditions, in the model calculation. In addition, we assumed a single value of $\mathrm{AE}$, which can be dependent on the food quality and quantity. However, the AEs may be much less variable compared to the $K d$ given the already high AEs in the scallops.

The biokinetic model predicts metal bioaccumulation in invertebrates and fish (Wang et al. 1996, Luoma \& Rainbow 2005, Zhang \& Wang 2007), but validation of this model is rather limited because of the lack of field data, especially with the available growth rate. Several studies only focused on the relative importance of metal uptake from the dissolved phase versus the dietary phase (Chong \& Wang 2001, Ke \& Wang 2001). There have been even fewer studies on the allometric effects on metal bioaccumulation in marine bivalves. Our results demonstrate that the process controlled by metabolic needs and environmental conditions such as food quality/quantity, temperature, and water flow rate. Small individuals tend to ingest more food per unit weight because of their higher needs for growth. On the other hand, small scallops may have different diets in terms of size or quality. Since metal concentrations decrease with increasing size in suspended particles in natural waters, small scallops may be more susceptible to metal uptake from food.

To conclude, our study demonstrated that scallops had a high capacity for accumulating $\mathrm{Cd}$ and $\mathrm{Zn}$ from both the dissolved and dietary phases. The efflux rates of $\mathrm{Cd}$ in the scallops were lower than those in most other bivalves, whereas those of $\mathrm{Zn}$ were comparable to those in other bivalves. The high $\mathrm{Cd} \mathrm{AE}$ and low efflux rate partly explained the high $\mathrm{Cd}$ concentrations in scallops. In contrast to $\mathrm{Cd}$, Zn was less assimilated and depurated faster. Body size was an important factor in metal bioaccumulation in scallops because of its influence on metal uptake from waterborne and dietary pathways. The influx rate from the dissolved phase decreased, whereas the AE increased with body size. Dietary uptake dominates the overall metal accumulation in scallops; thus, the decreased ingestion rate with increased body size was mainly responsible for the decreased bioaccumulation. The biokinetic model can predict both the allometric coefficient and concentration of metals in scallops of different sizes. 
Acknowledgements. We thank the 3 anonymous reviewers for their comments on this work. This study was supported by a Competitive Earmarked Research Grant from the Hong Kong Research Grants Council (HKUST6420/06M) to W.X.W.

\section{LITERATURE CITED}

Bargagli R, Nelli L, Ancora S, Focardi S (1996) Elevated cadmium accumulation in marine organisms from Terra Nova Bay (Antarctica). Polar Biol 16:513-520

Bartholomew GA (1981) A matter of size: an examination of endothermy in insects and terrestrial vertebrates. In: Heinrich B (ed) Insect thermoregulation. Wiley, New York, p 45-78

Bjerregaard P, Depledge MH (1994) Cadmium accumulation in Littorina littorea, Mylitus edulis and Carcinus maenas: the influence of salinity and calcium ion concentrations. Mar Biol 119:385-395

Blackmore G, Wang WX (2002) Uptake and efflux of Cd and $\mathrm{Zn}$ by the green mussel Perna viridis after metal preexposure. Environ Sci Technol 36:989-995

Boyden CR (1974) Trace element content and body size in mollusks. Nature 251:311-314

Brillant MGS, MacDonald BA (2000) Postingestive selection in the sea scallop, Placopecten magellanicus (Gmelin): the role of particle size and density. J Exp Mar Biol Ecol 253: 211-227

Bryan GW (1973) The occurrence and seasonal variation of trace metals in the scallops Pecten maximus (L.) and Chamys opercularis (L.). J Mar Biol Assoc UK 53:145-166

> Bustamante P, Miramand P (2004) Interspecific and geographical variations of trace element concentrations in Pectinidae from European waters. Chemosphere 57:1355-1362

Bustamante P, Miramand P (2005) Subcellular and body distributions of 17 trace elements in the variegated scallop Chlamys varia from the French coast of the Bay of Biscay. Sci Total Environ 337:59-73

- Calow P, Fletcher CR (1972) A new radiotracer technique involving ${ }^{14} \mathrm{C}$ and ${ }^{51} \mathrm{Cr}$ for estimating the assimilation efficiencies of aquatic, primary consumers. Oecologia 9:155-170

Chong K, Wang WX (2000) Assimilation of cadmium, chromium, and zinc by the green mussel Perna viridis and the clam Ruditapes philippinarum. Environ Toxicol Chem 19: 1660-1667

> Chong K, Wang WX (2001) Comparative studies on the biokinetics of $\mathrm{Cd}, \mathrm{Cr}$, and $\mathrm{Zn}$ in the green mussel Perna viridis and the Manila clam Ruditapes philippinarum. Environ Pollut 115:107-121

Cranford PJ, Gordon DC (1992) The influence of dilute clay suspensions on sea scallop (Placopecten magellanicus) feeding activity and tissue growth. Neth J Sea Res 30: $107-120$

Cranford PJ, Armsworthy SL, McGee S, King T, Lee K (2006) Scallops as sentinel organisms for offshore environmental monitoring. In: Armsworthy SL, Cranford PJ, Lee K (eds) Offshore oil and gas environmental effects monitoring: approaches and technologies. Lewis Publishers, Boca Raton, FL, p 25-35

Environmental Protection Department (EPD) (2005) Marine water quality in Hong Kong, 2005. Government of the Hong Kong Special Administration Region, Hong Kong

Evtushenko ZS, Lukyanova NN, Belcheva NN (1990) Cadmium bioaccumulation in organs of scallop Mizuhopecten yessoensis. Mar Biol 104:247-250

Fisher NS, Stupakoff I, Sañudo-Wihelmy S, Wang WX, Teyssié JL, Fowler SW, Crusius J (2000) Trace metal in marine copepods: a field test of a bioaccumulation model coupled to laboratory uptake kinetic data. Mar Ecol Prog Ser 194:211-218

> Fowler BA, Gould E (1988) Ultrastructural and biochemical studies of intracellular metal-binding patterns in kidney tubule cells of the scallop Placopecten magellanicus following prolonged exposure to cadmium or copper. Mar Biol 97:207-216

Fox HM, Ramage HA (1931) A spectrographic analysis of animal tissue. Proc R Soc Lond B Biol Sci 108:157-173

> George SG, Pirie BJS, Coombs TL (1980) Isolation and elemental analysis of metal-rich granules from the kidney of the scallop, Pecten maximus (L.). J Exp Mar Biol Ecol 42: 143-156

- Gould E, Thompson RJ, Buckley LJ, Rusanowsky D, Sennefelder GR (1988) Uptake and effects of copper and cadmium in the gonad of the scallop Placopecten magellanicus: concurrent metal exposure. Mar Biol 97:217-233

Jones HD, Richards OG, Southern TA (1992) Gill dimensions, water pumping rate and body size in the mussel Mytilus edulis L. J Exp Mar Biol Ecol 155:213-237

> $\mathrm{Ke} \mathrm{CH}$, Wang WX (2001) Bioaccumulation of metals (Cd, Se, and $\mathrm{Zn}$ ) in an estuarine oyster (Crassostrea rivularis) and a coastal oyster (Saccostrea glomerata). Aquat Toxicol 56: $33-51$

Lee BG, Wallace WG, Luoma SN (1998) Uptake and loss kinetics of $\mathrm{Cd}, \mathrm{Cr}$, and $\mathrm{Zn}$ in the bivlaves Potamocorbula amurensis and Macoma bathica: effects of size and salinity. Mar Ecol Prog Ser 175:177-189

Lukyanova ON, Belcheva NN, Chelomin VP (1993) Cadmium bioaccumulation in the scallop Mizuhopecten yessoensis from an unpolluted environment. In: Dallinger R, Rainbow PS (eds) Ecotoxicology of metals in invertebrates. Lewis Publishers, Boca Raton, FL, p 25-35.

Luoma SN, Rainbow PS (2005) Why is metal bioaccumulation so variable? Biodynamics as a unifying concept. Environ Sci Technol 39:1921-1931

> MacDonald BA, Thompson RJ (1986) Influence of temperature and food availability on the ecological energetics of the giant scallop Placopecten magellanicus. III. Physiological ecology, the gametogenic cycle and scope for growth. Mar Biol 93:37-48

Metian M, Bustamante P, Hedouin L, Warnau M (2007a) Accumulation of nine metals and one metalloid in the tropical scallop Comptopallium radula from coral reefs in New Caledonia. Environ Pollut 152(3):543-552

Metian M, Warnau M, Oberhnsli F, Teyssie JL, Bustamante P (2007b) Interspecific comparison of Cd bioaccumulation in European Pectinidae (Chlamys varia and Pecten maximus). J Exp Mar Biol Ecol 353:58-67

Neff JM (2002) Bioaccumulation in marine organisms: effects of contaminants from oil well produced water. Elsevier, Amsterdam, p 89-102

Newman MC, Heagler MG (1990) Allometry of metal bioaccumulation and toxicity. In: Newman MC, McIntosh AW (eds) Metal ecotoxicology: concepts and applications. Lewis Publishers, Chelsea, MI, p 91-125

Ng TYT, Wang WX (2005) Modeling Cd bioaccumulation in two populations of the green mussel Perna viridis. Environ Toxicol Chem 24:2299-2305

Peters R (1983) The ecological implications of body size. Cambridge University Press, New York, p 1-139

- Rainbow PS (2002) Trace metal concentrations in aquatic invertebrates: Why and so what? Environ Pollut 120:497-507

> Reinfelder JR, Fisher NS, Luoma SN, Wang WX (1998) Trace element trophic transfer in aquatic organisms: a critique of the kinetic model approach. Sci Total Environ 219: 117-135 
Stone HC, Wilson SB, Overnell J (1986) Cadmium-binding proteins in the scallop Pecten maximus. Environ Health Perspect 65:189-191

Uthe JF, Chou CL (1987) Cadmium in sea scallop (Placopecten magellanicus) tissues from clean and contaminated areas. Can J Fish Aquat Sci 44:91-98

Viarengo A, Canesi L, Mazzucotelli A, Ponzano E (1993) Cu, $\mathrm{Zn}$ and $\mathrm{Cd}$ content in different tissues of the Antarctic scallop Adamussium colbecki: role of metallothionein in heavy metal homeostasis and detoxification. Mar Ecol Prog Ser 95:163-168

Wang WX (2001) Comparison of metal uptake rate and absorption efficiency in marine bivalves. Environ Toxicol Chem 20:1367-1373

Wang WX (2003) Metal bioaccumulation in bivalve mollusks: recent progress. In: Villalba A, Reguera B, Romalde JL,

Editorial responsibility: Joseph Pawlik, Wilmington, North Carolina, USA
Beiras R (eds) Molluscan shellfish safety. Intergovernmental Oceanographic Commission of UNESCO and Conselleria de Pesca e Asuntos Maritimos da Xunta de Galicia, Santiago de Compostela, p 503-520

Wang WX, Fisher NS (1996) Assimilation of trace elements and carbon by the mussel Mytilus edulis: effects of food composition. Limnol Oceanogr 41:197-207

Wang WX, Fisher NS (1999) Assimilation efficiencies of chemical contaminants in aquatic invertebrates: a synthesis. Environ Toxicol Chem 18:2034-2045

> Wang WX, Fisher NS, Luoma SN (1996) Kinetic determinations of trace element bioaccumulation in the mussel Mytilus edulis. Mar Ecol Prog Ser 140:91-113

Zhang L, Wang WX (2007) Size-dependence of the potential for metal biomagnification in early life stages of marine fish. Environ Toxicol Chem 26:787-794

Submitted: October 1, 2007; Accepted: February 18, 2008

Proofs received from author(s): July 16, 2008 